\title{
Seasonal variation in semen quality: effect of temperature: a study in North India
}

\author{
Kirti Balhara $^{1}$, Sarika Singh ${ }^{1 *}$, Sunita Sharma ${ }^{2}$
}

\author{
${ }^{1}$ Department of Pathology, Maulana Azad Medical College, New Delhi, India \\ ${ }^{2}$ Department of Pathology, Lady Hardinge Medical College, New Delhi, India
}

Received: 19 December 2021

Accepted: 13 January 2022

\section{*Correspondence:}

Dr. Sarika Singh,

E-mail: sarikasingh97b@gmail.com

Copyright: ( $)$ the author(s), publisher and licensee Medip Academy. This is an open-access article distributed under the terms of the Creative Commons Attribution Non-Commercial License, which permits unrestricted non-commercial use, distribution, and reproduction in any medium, provided the original work is properly cited.

\begin{abstract}
Background: Variable temperature in different seasons may affect the quality of semen. Most of the studies are from west barring a single large Chinese study with variable results; however, no such study focusing on temperature alone has been published from Indian subcontinent. Present study was undertaken to observe any seasonal variation affecting the semen quality at different times of year.

Methods: The study was conducted retrospectively over one year period (2014-2015) at a tertiary care hospital in North India. 815 semen samples referred from infertility clinic were analysed for Sperm concentration, functional sperm concentration, motile sperm concentration and sperm motility index by an automated semen analyser system (SQAIIC-P, Medical Electronic Systems, Los Angeles, CA, USA); and morphological assessment by Papanicolaou stained smears. Statistical analysis was done using SPSS 24 software (SPSS Inc, Chicago, IL, USA). The ANOVA test was used to assess differences in semen parameters, $\mathrm{p}<0.05$ was considered as statistically significant.

Results: Depending on the average highest temperature (AHT) in different seasons, samples were categorized in four groups: winter AHT $<10^{\circ} \mathrm{C}$, spring AHT $<20^{\circ} \mathrm{C}$, autumn/rainy season AHT $20-30^{\circ} \mathrm{C}$ and summer AHT $>30^{\circ} \mathrm{C}$. There was significant variation on different parameters e.g. sperm count, motility, FSC, MSC, SMI, abnormal sperms and morphological defects when compared in different groups using ANOVA test $(\mathrm{p}<0.05)$.

Conclusions: Present study observed that AHT of $20-30^{\circ} \mathrm{C}$ (autumn) has a favourable effect on semen quality; however, larger and continuous data in the form of longitudinal study is needed for better correlation.
\end{abstract}

Keywords: Semen quality, Male infertility, Temperature

\section{INTRODUCTION}

Infertility is a global public health concern. It is defined as the inability of a reproductive age couple cohabiting together to conceive after one year of unprotected intercourse. Approximately $15 \%$ of couples are infertile worldwide and, around $20-70 \%$ of these are attributed to male infertility factors. ${ }^{1,2}$ The extensive published data suggest that semen quality is declining globally., ${ }^{3,4}$ Of the multitude of variables studied so far, temperature is most important yet least studied parameter. The present study aimed to observe the effect of temperature on semen quality in different seasons in a year.

\section{METHODS}

This retrospective study was conducted over the period of one year (July 2014 to June 2015) at a tertiary care hospital of North India. 815 semen samples referred from the infertility clinic were analysed. The donors ranged in age from 20 to 52 years, sexual abstinence of 3-7 days was followed. The samples were collected in the laboratory and processed within 30 minutes of collection as per the standard protocol. Depending on the average highest temperature (AHT) in different seasons, the samples were categorized in four groups: winter AHT 
$<10^{\circ} \mathrm{C}$, spring $\mathrm{AHT}<20^{\circ} \mathrm{C}$, autumn/rainy season $\mathrm{AHT}$ $20-30^{\circ} \mathrm{C}$ and summer AHT $>30^{\circ} \mathrm{C}$ (Table 1$)$.

Table 1: Distribution of semen samples under various groups as per AHT.

\begin{tabular}{|llll|}
\hline Groups & AHT $_{-}\left({ }^{\circ} \mathrm{C}\right)$ & $\mathrm{N}$ & $\begin{array}{l}\text { Months } \\
\text { Winter }\end{array}$ \\
$\leq 10$ & 200 & $\begin{array}{l}\text { November- } \\
\text { January }\end{array}$ \\
\hline Spring & $10.1-20.0$ & 186 & $\begin{array}{l}\text { February- } \\
\text { April }\end{array}$ \\
\hline Autumn/ rainy & $20.1-30$ & 197 & $\begin{array}{l}\text { August- } \\
\text { October }\end{array}$ \\
\hline Summer & $>30$ & 232 & May-July \\
\hline
\end{tabular}

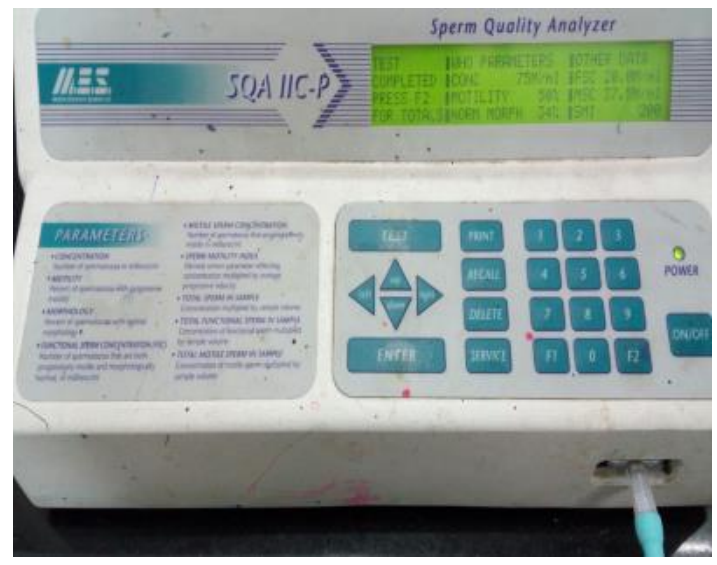

Figure 1: Automated sperm analyser, Sysmex-SQIIC.

For each sample, sperm concentration (SC), motility (SM), functional sperm concentration (FSC), motile sperm concentration (MSC) and sperm motility index (SMI) were conducted as per WHO guideline $2010^{5}$ on SQAIIC-P (Medical electronic systems, Los Angeles, CA, USA). Sperm morphology was assessed on Papanicolaou stained (Pap) smear after centrifugation of the remaining sample; two smears were prepared from each sample and a minimum of 200 spermatozoa were counted. In every sample, number of sperms with normal morphology (NM), head defect (HD), midpiece defect (MPD), cytoplasmic defect (CD) and tail defect (TD) were recorded following Tygerberg Kruger strict morphological criteria. Results were expressed as mean, median and standard deviation. Various groups were created as per season, as per average highest temperature. Statistical analysis was done using SPSS 24 software (SPSS Inc, Chicago, IL, USA). The ANOVA test was used to assess differences in semen parameters, $\mathrm{p}<0.05$ was considered as statistically significant.

\section{RESULTS}

Donors ranged in age from 20-52 years (median age-28 years). Volume of semen ranged from $0.5-2.5 \mathrm{~mL}$. Sperm concentration ranged from 1-189 million/ml, with a mean of $37.48 \pm 32.40 \mathrm{million} / \mathrm{ml}$. The highest $\mathrm{SC}$ was observed in autumn, followed by summer and spring (AHT $>10^{\circ} \mathrm{C}$ ), while winter season showed lowest $\left(\mathrm{AHT}<10^{\circ} \mathrm{C}\right.$ ). Percentage of SM ranged from 1-83 (mean $32.26 \pm 15.67$ ). Lowest SM were found in winter (AHT< $10^{\circ} \mathrm{C}$ ) and maximum in autumn followed by summer and spring (AHT $\left.>10^{\circ} \mathrm{C}\right)$. A similar pattern was noted in FSC, MSC \& SMI with highest concentrations in autumn followed by summer, spring, and winter. A significant effect of AHT variation was seen on all semen parameters $(\mathrm{p}=0.000)$. SC and SM were significantly lower in winter $\left(\mathrm{AHT}<10^{\circ} \mathrm{C}\right)$ than in other seasons $(\mathrm{p}=0.000)$. The mean of sperms with $\mathrm{NM}$ was lowest in spring $\left(\mathrm{AHT}=10.1-20^{\circ} \mathrm{C}\right)$ and highest in autumn $\left(\mathrm{AHT}=20.1-30^{\circ} \mathrm{C}\right)$ followed by summer $\left(\mathrm{AHT}>30^{\circ} \mathrm{C}\right)$. The mean HDs decreased significantly in autumn and winter and, increased significantly in spring followed by summer $(\mathrm{p}=0.000)$. The mean of MPD was maximum in summer and winter while it was lowest in autumn $(p=0.000)$. The lowest mean of TD was observed in autumn and, highest in winter $(p=0.000)$. CD were maximum in winter and minimum in summer $(\mathrm{p}=0.000)$ (Table 2-4).

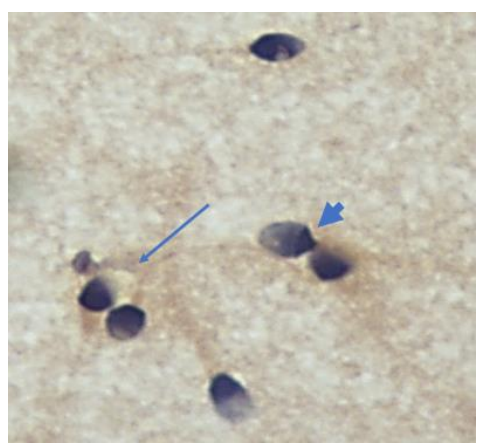

Figure 2: Abnormal sperms showing tapered head (arrowhead), amorphous head (arrow), Papanicolaou stain, X1000.

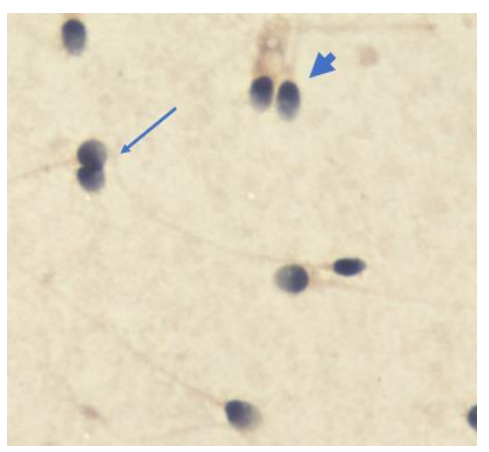

Figure 3: Abnormal sperms showing small round double heads (arrow), mid piece defect (arrowhead), Papanicolaou stain, X1000.

\section{DISCUSSION}

The initial evaluation in a case of male factor infertility relies on semen analysis and various parameters are assessed on semen analysis i.e. volume, SC, SM 
(progressive \& non progressive), sperm morphology, $\mathrm{pH}$

and SMI. along with newer automated parameters like FSC, MSC

Table 2: Age distribution with semen parameters.

\begin{tabular}{|lllll|}
\hline Semen parameter & Mean & MD) & Minimum & Maximum \\
\hline Age & 29.73 & 5.77 & 20 & 52 \\
\hline Concentration* (sperm/ml) & 37.48 & 32.40 & 1 & 189 \\
\hline Motility $\mathbf{( \% )}$ & 32.26 & 15.67 & 2 & 83 \\
\hline Normal morphology $\boldsymbol{\dagger}(\mathbf{\%})$ & 76.37 & 35.88 & 198 \\
\hline
\end{tabular}

*Number of sperm X $10^{6}, \dagger$ Tygerberg Kruger strict morphology ${ }^{16}$

Table 3: Seasonal variations of semen parameters.

\begin{tabular}{|c|c|c|c|c|c|c|c|}
\hline \multicolumn{2}{|l|}{ Semen parameter } & Winter $\ddagger$ & Spring $\ddagger$ & Summer & Autumn/rainy $\ddagger$ & F value & $P$ value \\
\hline \multirow{3}{*}{$\begin{array}{l}\text { Sperm concentration* } \\
(\mathrm{sperm} / \mathrm{ml})\end{array}$} & Median & 22.5 & 24 & 27 & 36 & & \\
\hline & Mean & 29.82 & 31.91 & 37.80 & 50.13 & & \\
\hline & SD & 23.21 & 26.05 & 32.33 & 41.13 & 16.243 & 0.000 \\
\hline \multirow{3}{*}{ Motility (\%) } & Median & 27 & 30 & 32 & 36 & & \\
\hline & Mean & 29.04 & 29.82 & 33.01 & 36.94 & & \\
\hline & SD & 13.20 & 14 & 15.87 & 17.95 & 10.156 & 0.000 \\
\hline \multirow{3}{*}{ FSC } & Median & 2.1 & 2.35 & 2.8 & 4.7 & & \\
\hline & Mean & 5.64 & 6.80 & 9.54 & 16.91 & & \\
\hline & SD & 8.85 & 11 & 15.56 & 23.34 & 17.876 & 0.000 \\
\hline \multirow{3}{*}{ MSC } & Median & 5.7 & 6.7 & 8.3 & 12.9 & & \\
\hline & Mean & 11.11 & 12.67 & 17.01 & 26.25 & & \\
\hline & SD & 13.82 & 11 & 22.01 & 30.49 & 19.003 & 0.000 \\
\hline \multirow{3}{*}{ SMI } & Median & 65 & 70 & 76.5 & 95 & & \\
\hline & Mean & 84.94 & 92.08 & 105.76 & 138.19 & & \\
\hline & SD & 60.15 & 67.96 & 82.22 & 106.79 & 16.100 & 0.000 \\
\hline
\end{tabular}

*Number of sperm X 106, ‡ number of subjects for sperm concentration, motility, FSC, MSC, SMI (winter=200, spring=186, summer=232, autumn/rainy $=197$ )

Table 4: Seasonal variations in sperm morphology (Papanicolaou smears on 200 spermatozoa count).

\begin{tabular}{|c|c|c|c|c|c|c|c|}
\hline Morphology* & & Winter $\neq$ & Spring $\ddagger$ & Summer $\neq$ & Autumn/rainy $\ddagger$ & F value & P value \\
\hline \multirow{3}{*}{ Normal } & Median & 70 & 67 & 64.5 & 104 & & \\
\hline & Mean & 67.87 & 64.97 & 69.48 & 103.86 & & \\
\hline & SD & 31.49 & 25.51 & 37.73 & 32.17 & 63.962 & 0.000 \\
\hline \multirow{3}{*}{ Head defect } & Median & 102.5 & 124.5 & 128.5 & 70 & & \\
\hline & Mean & 104.8 & 125.67 & 123.73 & 74.82 & & \\
\hline & SD & 32.10 & 27.05 & 38.42 & 29.04 & 104.555 & 0.000 \\
\hline \multirow{3}{*}{ Midpiece defect } & Median & 27 & 15 & 33.5 & 12 & & \\
\hline & Mean & 29.07 & 21.40 & 38.67 & 16.17 & & \\
\hline & SD & 19.81 & 19.77 & 26.10 & 14.22 & 43.283 & 0.000 \\
\hline \multirow{3}{*}{ Tail defect } & Median & 24 & 16 & 19.5 & 11 & & \\
\hline & Mean & 29.35 & 21.51 & 25.07 & 14.76 & & \\
\hline & SD & 21.63 & 19.31 & 20.17 & 12.87 & 15.959 & 0.000 \\
\hline \multirow{3}{*}{ Cytoplasmic defect } & Median & 70.5 & 50 & 5 & 30 & & \\
\hline & Mean & 70.83 & 54.52 & 12.81 & 40.06 & & \\
\hline & SD & 36.34 & 26.64 & 16.08 & 26.51 & 131.877 & 0.000 \\
\hline
\end{tabular}

*Tygerberg Kruger strict criteria, łnumber of subjectsfor normal morphology, head defect, midpiece defect, tail defect, cytoplasmic defect (winter=200, spring=186, summer=232, autumn/rainy=197).

Seasonal variation in semen parameters has been studied in the past with controversial results; ${ }^{6-10}$ some observed significant variations in parameters while others showed no effect of seasonal variation on semen quality whatsoever. ${ }^{9,11}$ To the best of literature search no such study has been published from Indian subcontinent. 
The present study observed a significant effect of seasonal variation on all semen parameters.

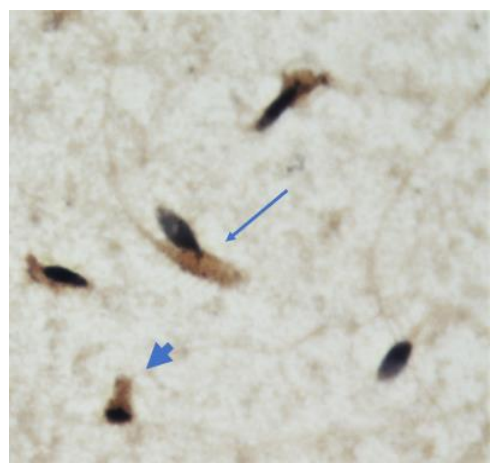

Figure 4: Abnormal sperms showing tapered head and bent neck (arrow), mid piece defect and absent tail (arrowhead), Papanicolaou stain, X1000.

The lowest $\mathrm{SC}$ was noticed in winter $\left(\mathrm{AHT}<10^{\circ} \mathrm{C}\right)$, and the highest in Autumn (AHT 20.1-30 ${ }^{\circ} \mathrm{C}$ ). The correlation of SC in both these seasons was highly significant $(p=0.000)$; however, Carlsen et al and Chen et al reported no seasonal change in SC. ${ }^{9,12}$ SM also showed similar variation with minimum in winter and maximum in autumn $(\mathrm{p}=0.006)$; these observations were different from earlier reports by Yogev et al and Chen et al that showed that SM did not change with seasonal variations. ${ }^{8,12}$ Automated semen parameters (FSC, MSC and SMI) have not been previously studied earlier. In the present study highest levels of functional and motile sperms were observed in autumn and lowest in winter with a significantly high $\mathrm{p}$ value $(\mathrm{p}=0.000)$ in each. Mature sperm/spermatozoon is an actively motile, highly specialized, free swimming cell; with various parts (head, neck, middle piece and a principal piece or tail. An axial filament passes through the middle piece and extends into the tail. Mature sperm measures approximately $60 \mu \mathrm{m}$ in length. ${ }^{13}$ Therefore any variations from normal will make spermatozoa abnormal morphologically and or functionally, thus it is imperative to look into morphology as well in investigating a case of male infertility. In the present study, sperms with NM were maximum in autumn followed by spring, winter and lowest in summer $(\mathrm{p}=0.000)$. HD, MPD and TD were significantly lower in autumn while $\mathrm{CD}$ were lowest in summer followed by autumn $(\mathrm{p}=0.000)$. HD were maximum in spring (AHT: $\left.10.1-20^{\circ} \mathrm{C}\right)(\mathrm{p}=0.000)$; MPD in summer $\left(\mathrm{AHT}>30^{\circ} \mathrm{C}\right)(\mathrm{p}=0.000)$ while $\mathrm{CD}$ and $\mathrm{TD}$ were maximum in winter $\left(\mathrm{AHT}<10^{\circ} \mathrm{C}\right)$ with $\mathrm{p}=0.000$. Changes in testicular temperature could impact synthesis and repair of DNA in sperm head which can be the reason for the seasonal variation of HD. ${ }^{14} \mathrm{~A}$ positive correlation between HD and DNA abnormality was observed by Varghese et al. ${ }^{15}$

\section{Limitations}

Due to smaller sample size and absence of follow up of same patients in different seasons, more elaborate and consistent longitudinal study is warranted to further improve the knowledge about the effects of AHT on semen parameters.

\section{CONCLUSION}

The present study observed significant variations on sperm quality under different temperature and; autumn season was the best (AHT-20.1-30 ${ }^{\circ} \mathrm{C}$ ) with all parameters including calculated values through analyzer (SC, SM, FSC, MSC, SMI) and morphological parameters on Pap smears (NM, HD, MPD, TD). However, CD did not show any consistent pattern with changing temperature.

\section{Funding: No funding sources \\ Conflict of interest: None declared \\ Ethical approval: The study was approved by the Institutional Ethics Committee}

\section{REFERENCES}

1. Salas-Huetos A, Bullo M, Salas-Salvado J. Dietary patterns, foods and nutrients in male fertility parameters and fecundability: a systematic review of observational studies. Hum Reprod. 2017;23:371-89.

2. Agarwal A, Mulgund A, Hamada A, Chyatte MR. A unique view on male infertility around the globe. Reprod Biol Endocrinol. 2015;13:37.

3. Carlsen E, Giwercman A, Keiding N, Skakkebaek NE. Evidence for decreasing quality of semen during past 50 years. BMJ. 1992;305:609-13.

4. Swan SH, Elkin EP, Fenster L. The question of declining sperm density revisited:An analysis of 101 studies published 1934-1996. Environ Health Perspect. 2000;108:961-6.

5. Cooper TG. WHO laboratory manual for the examination and processing of human semen. 5th ed. Switzerland: WHO Press; 2010.

6. Levine RJ. Male factors contributing to the seasonality of human reproduction. Annals New York Acad Sci. 1994;709:29-45.

7. Henkel R, Menkveld R, Kleinhappl M, Schill WB. Seasonal changes in human sperm chromatin condensation. J Assisted Reprod Gen. 2001;18(7): 371-7.

8. Yogev L, Kleiman S, Shabtai E, Botchan A, Gamzu $\mathrm{R}, \mathrm{Paz} \mathrm{G}$ et al. Seasonal variations in pre- and postthaw donor sperm quality. Human Reprod. 2004; 19:880-5.

9. Carlsen E, Petersen JH, Andersson AM, Skakkebaek NE. Effects of ejaculatory frequency and season on variations in semen quality. Fertil Steril. 2004; 82(2):358-66.

10. Chen Z, Godfrey-Bailey L, Schiff I. Impact of seasonal variation, age and smoking status on human semen parameters: The Massachusetts General Hospital experience. J Exp Clin Assist Reprod. 2004; 1: 2 .

11. Gyllenborg J, Skakkebaek NE, Nielsen NC, Keiding $\mathrm{N}$, Giwercman A. Secular and seasonal changes in 
semen quality among young Danish men: a statistical analysis of semen samples from 1927 donor candidates during 1977-1995. Int J Androl. 1999; 22(1):28-36.

12. Chen Z, Toth T, Godfrey-Bailey L, Mercedat N, Schiff I, Hauser R. Seasonal variation and age-related changes in human semen parameters. J Androl. 2003;24(2): 226-31.

13. Singh I, Devi VS. Human Embryology. 11th ed. New Delhi: Jaypee Brothers Medical Publishers; 2018:301.

14. González-Marín C, Gosálvez J, Roy R. Types, causes, detection and repair of DNA fragmentation in animal and human sperm cells. Int J Mol Sci. 2012;13(11): 14026-52.

15. Varghese AC, Bragais FM, Mukhopadhyay D, Kundu S, Pal M, Bhattacharyya AK et al. Human sperm
DNA integrity in normal and abnormal semen samples and its correlation with sperm characteristics. Andrologia. 2009;44(4):207-15.

16. Kruger TF, DuToit TC, Franken DR, Acosta AA, Oehninger SC, Menkveld $\mathrm{R}$, et al. A new computerized method of reading sperm morphology (strict criteria) is as efficient as technician reading. Fertil Steril. 1993;59(1):202-9.

Cite this article as: Balhara K, Singh S, Sharma S. Seasonal variation in semen quality: effect of temperature: a study in North India. Int J Reprod Contracept Obstet Gynecol 2022;11:547-51. 